\title{
Growth Governance Nexus: A Case of Pakistan
}

\author{
*RabiaNazir, Muhammad Nadeem,Mumtaz Anwar \\ University of the Punjab Lahore, Pakistan \\ *rabia.nazir@iub.edu.pk
}

\begin{abstract}
Good governance has gained tremendous importance in the development agenda of developing economies since 1990s but growth literature gives mixed picture about the role of governance and institutional factors in explaining GDP growth. The present study is an attempt to provide empirical evidence on interlinks between governance and GDP growth. ADF and Johansen co-integration tests are applied for econometric testing of the hypothesis by using time series data from 1984 to 2010 . All the variables turned out to be significant with ICRG (proxy used for governance) having positive and significant impact on GDP growth of Pakistan. Results of the study have shown that governance plays major role in determining GDP growth pattern of Pakistan. A complete reform of the political, economic system, judiciary, bureaucracy and a free media are recommended to improve governance and to achieve sustained GDP growth in Pakistan consequently.
\end{abstract}

Keywords: Governance, GDP growth, $A D F$, Johansen co-integration, ICRG

\section{Introduction}

The procedures through which decisions are made and implemented are called governance. Governance is studied and analyzed at local, national and international levels by political theorists (Khan, 2006).Political governments as well as economic and administrative establishments use governance as a tool to manage affairs of their nation. Governance is the instrument of political, economic and administrative establishments to manage a nation's affairs (Chaudhry et al., 2009).Governance is divided into three main categories economic, political and administrative. Economic governance includes the process of decision making which governs economic activities of the countries and its economic links with other nations. Formulation of national policies is the subject of political governance and policy implementation is the task of administrative governance. Incorporating all three, good governance sets the procedures and structures to direct political and socio-economic relationships. Governance has gained tremendous importance by academicians, politicians, policy makersand international donor agencies like IMF and World Bank from the last decade. Due to this increased interest in governance many organizations are extensively engaged in measuring governance. Freedom House, The International Country Risk Guide, Transparency International Global Integrity, The Open Budget Project, The Global Competitiveness Index, CPIA (Country Performance and Institutional Assessment) and The Worldwide Governance Indicators Project are some famous of which. These indicators are widely used by the business public, aid donors and the academic community.

Present study is an attempt to check the macroeconomic role of governance for the performance of the economy. We find many empirical studies on the role of governance in affecting macroeconomic indicators. It is considered as the prerequisite for growth and development of societies now a day despite controversies and ambiguities about the concept. Kaufmann et al. (2002) and Chaudhry et al. (2009) claimed that good governance lead to higher economic growth via better and effective allocation of resources both of labor and capital. Governance reduces the burden of poverty and inequality as well as is a mean to provide better education, health, infrastructure and other public services. All above is facilitated either by government itself or by private sector being supervised by the public sector. Governance is both a cause and consequence of economic development (Maurseth \& Verspagen, 2009).Pakistan is faced with a wide range of challenges to the development of good governance. Challenges include a combination of general political instability, increased insecurity and sectarian violence, tensions with neighboring countries, a worsened economic situation, a rapid population increase, a limited tax income and high levels of corruption. In addition, frequent natural disasters havealso increased economic burden on population and Government of Pakistan. The nation state is weak with poorly defined structures, and the citizens have limited expectations of state performance and 
support, yet the citizens also have limited capacities to promote change. One explanation for this state of affairs is that Pakistan has witnessed four periods of military rule since gaining independence in 1947, the latest of which ended when President Musharraf resigned in August 2008 (Bauck et al., 2011).Due to above reasons, all the indicators of governance are showing a downward trend as can be seen from the report of global competitiveness index 2011. Table 1.1 given in appendix shows that Pakistan fells from $101^{\text {st }}$ to $123^{\text {rd }}$ place despite a modest fall in its score from 3.6 to 3.5. Table 1.2 and 1.3 are also showing poor situation on the pillar of institutions and macro stability where Pakistan's rank fells to 112 and 133 respectively. Moreover, Pakistan experienced largest reversals in country rank for Pakistan 2010 Indicators as compared to 2008-09.

Table 4 can be cited from appendix given below showing that all indicators like Inflation (change in CPI), Interest rate spread, Trade Tariffs/Tariff barriers, Rigidity of employment, Agricultural policy costs, Total tax rate, Internet users, Burden of government regulation, Strength of auditing and reporting standards, Quality of overall infrastructure, Hiring and firing practices, Flexibility of wage determination, Transparency of government in policymaking, Tuberculosis incidence (per $100 \mathrm{~K}$ people) and Organized crime have experienced a downfall as being incorporated with negative sign of difference from 2008-09 to 2011. Same trend has been observed on world governance indicators (1996-2010). Figures in appendix are showing percent score (0-100) of Pakistan and overall percentile rank. Therefore, it can be clearly concluded that Pakistan is placed in lowest rank on governance performance. The aforementioned factors constitute a demanding set of challenges that cannot be addressed without addressing the issue of good governance.Thus the deteriorating situation in terms of governance in Pakistan calls for identifying its importance for the economy of Pakistan. The study is designed to check governance impact on GDP growth of Pakistan. For this purpose, we have conducted a time series study regressing ICRG (governance indicator) on GDP growth. The results have shown that governance is affecting GDP significantly. This study recommends improving governance in Pakistan to ensure a good pace of economic growth.Rest of the paper is organized as follows: section II is a brief literature review. In Section III hypothesis has been drawn on the basis of existing literature. Section IV outlines the methodology and gives a description of data and data sources. Results are displayed in section V and section VI concludes the study by suggesting some important policy measures.

\section{Literature Review}

Firstly, we have explored the relation between governance and GDP growth of the economy. In 1775 Adam Smith, founder of economics, claimed governance as a prerequisite for economic growth in his lecturer to Glasgow audience. He said:

"Little else is requisite to carry a state to the highest degree of opulence from the lowest barbarism than peace, easy taxes, and tolerable administration of justice; all the rest being brought about by the natural course of things."

Kormendi and Meguire (1985) conducted an empirical study to determine impact of civil liberty on the growth rate of 47 countries from years 1950-77. They found that the countries with higher civil liberties experienced higher growth rate.Khan (2006) found that distribution of income, change in distribution and economic development led to reduce poverty. Moreover governance also effect income growth and distribution in a positive and significant way. Barro (1991) determined the impact of political instability on growth by using two violence measures (average annual number of riots and political killings).He found asignificant negative impact of these measures on GDP growth rate and private investment's share of GDP.Keefer and Knack (1997) concluded that economic growth of the economy is greatly influenced by contract rights and property rights like institutions.Campos and Nugent (1999) supported the same idea that governance affects economic development of the economy significantly.

Pasha (2000) identified nine elements of good economic governance as achievement of growth with equity, fiscal discipline, institutional capacity, credibility and consistency, protection of public interest, ability to manage crisis, effective delivery of services, integrity and sovereignty. He brings out mixed evidence as some of the indicators show good economic governance whereas the others indicate poor performance. He said that if Pakistan wants to improve its GDP growth, it wouldhave to improve its economic governance significantly. Knack (2002) used data of 40 non-industrialized nations from 18501950, considering ICRG, initial gross domestic product per capita, average educational achievement, the $\log$ of inflation, the year-to-year variability of inflation, M2/GDP and exports/GDP as major variables. His 
empirical analysis showed good governance in total as a pre-condition for sustained and stable economic growth. Political organization and administrative quality of government was the most crucial element of governance in his study. Kaufmann et al. (2004) suggested a strong positive correlation between growth and governance. They used such an empirical technique, which distinguished the correlation in two separate types. First was a positive causal relationship between good governance and growth. Nevertheless, the causality from growth to governance was weak and negative. This evidence suggested that there was no "virtuous Circles" in which improvement in governance was not dependent on higher income.

Mawdsley and Rigg (2003) claimed that strong and efficient institutions are very essential for sustained economic growth at local, international, national and global levels. This idea has been supported by many empirical studies, which have attributed difference in growth of different countries to the quality of institutions of those countries. Good governance enhances economic growth of the countries through quantity and quality channels. Quantity channel works through stock of capital and quality channel operates through reduction in income inequality of the country. If a country is suffering from low quality governance then all of its efforts to develop infrastructure, induce investment and to increase literacy rate will be wasted. Hence, poor governance despite working in other areas leads economy to poverty traps. Hussain (2005) claimed that macro-economic instability, low GDP growth and failure to provide public services are result of poor governance and low capacity of key institutions of the economy. He claimed that a politics free, long term and strategic approach free of self-interest is a pre requisite for good economic governance and development of strong institutions. In addition, continuation of policies was deemed necessary for a long run process of the development of strong institutions.Chauvet and Collier (2004) conducted a cross section analysis and proved that on average $2.3 \%$ slower GDP growth rate per annum was achieved by poor governing economies as compared to others. Shafique and Haq (2006) discussed quality and quantity channels 1 of good governance in their study based on the data of SAARC countries from 1996 to 2005 . They emphasized that government sector is really crucial for development but public sector efficiency is very low in these countries. The reason behind is high corruption and misallocation of resources. Resnick and Birner (2006) examined correlation between growth and different aspects of governance. They reviewed many cross-country studies and showed that growth was correlated with rule of law and political instability but their impact on poverty was not clear. While civil liberties and political freedom led to decrease poverty but their role for economic growth was unclear. Jalilian et al. (2007) using the from the period 1980-2000, keeping GDP per capita as dependent variable and Gross capital formation, Schooling, Trade, Inflation ,Government expenditures and governance indicators as explanatory variables supported the idea that in poor income economies higher income growth is conditional on good regulation. They said that efficiency and effectiveness of the regulatory quality isvery important for the outcome of regulation in studied countries.

Fayissa and Nsiah (2010) examined African economies from 1990 to 2004 to determine the impact of governance on their sub optimal growth while controlling the conventional sources of growth. The results proved that gap between incomes of the African countries were mainly due to the difference in governance performance. Moreover, governance impact on growth was conditional on the type and level of growth in the respective countries. Shafique and Haq (2006) using data from the period 1996-2005 investigated income distribution pattern of SARRC countries, the study chooses World Bank "Aggregate Governance Indicators 1996-2005" dataset for four countries; Bangladesh, India, Pakistan and Sri Lanka. The evidence showed that institutional/governance frame work is crucial for sustained economic development in addition to other public policies to affect allocation of resources for reduction of poverty and inequality. Kaufmann et al. (2002) identified relation between WGI (world governance indicators) and per capita incomes of all the countries and found a strong evidence of positive casual relation running from good governance to GDP. According to their estimates, one standard deviation in governance scale produced 3-fold effects on per capita in the long run.In an International conference on Framework for Economic Growth, Pakistan it was suggested that there are two key players to influence economic growth i.ethe government and the private sector which can work through affecting rural development, Private investment, Privatization, Trade and Good governance. Focus of governance should be to manage private sector through ensuring healthy competition and generation of new markets. Ensuring transparency and

${ }^{1}$ If the stock of capital is growing then it is quantity channel and if governance is changing the income inequality situation in the economy than it is working through quality channel. 
accountability in all economic activities and development of good quality institutions should be a priority in the agenda of governance reforms. Nevertheless, all these reforms require strong political support. Haq and Zia (2009) examined interlinks between pro poor growth and governance in Pakistan form 1996 to 2005. Their econometric analysis suggested a significant negative relation between governance and pro poor growth i.e. negative between governance and poverty. Hussain (2004)also supported that macroeconomic instability, unsustainable GDP growth and poor delivery of public services in Pakistan is due to weak economic governance and decline in quality of institutions.

Hypothesis Derivation: Literature on growth is full of empirical studies focusing on the conventional sources of growth like human and physical capital, labor force, trade, aid, FDI, geography and many other variables in the framework of neo-classical growth models. Nevertheless, since 1990s good governance has gained importance in the growth literature (Fayissa and Nsiah, 2010). Political factors were not given importance in growth literature before that. Reynolds (1983) conducted a study on 40 non-industrialized countries with political factors as major explanatory variables to check the long run growth pattern of these countries from 1850 to 1950 . He claimed that difference in growth of these economies was mainly due to the difference in the quality of institutions and political factors. Owens (1987) and Sen (1999) supported the need for economic and political freedom as part and parcel for economic growth in their theoretical discourses. Later on, since 1990s empirical literature focused on the lack of good governance for its influence on growth. Kaufmann and Kraay (2002) also claimed that differences in long run growth pattern of economies owes to the historical differences in the quality of their institutions. Channels through which governance affects growth works via the fact that better governance increases the level of investment, Solow (1957) and Kuznets (1966) proposed that economic growth is subject to productivity growth and empirical research shows that good macro-economic policies can enhance productivity. Olson et al. (2000) have incorporated the role of institutions in the neo classical framework of growth and their results showed that about $2 \%$ growth in productivity per annum could be realized due to improvement in the quality of institutions. It is the consensus of growth and development economists that there is a theoretical connection between governance and living standards. Where the incentives within a society lead wealth-maximizing individuals to produce new wealth rather than divertitaway from others, development is sure to follow, the theory predicts. Better quality of institutions leads to increase the investment rate, transparency of markets, reduces transaction costs and increases the productivity growth all of which in turn increase GDP growth of the country (Knack, 2002). We in this study have tested the hypothesis that whether good governance affects GDP growth of Pakistan significantly or not?

\section{Methodology}

Good governance accelerates growth by increasing output and productivity of labor and capital. In present study GDP (gross domestic product) as dependent variable while labor, gross fixed capital formation, trade openness, ICRG (international country risk guide, proxy for governance) and inflation has been used as explanatory variables. Annual time series data from 1984 to 2010 has been gathered from different sources like world value survey, world development indicators and IFS browser. CobbDouglas production function is used for analysis. The Cobb-Douglas (Cobb and Douglas, 1928) function is a particular form of production function. We started with basic cob-Douglas production function as:

$$
Y=\alpha K \beta 1 L \beta 2
$$

WhereY = output, $\mathrm{K}=$ capital stock, $\mathrm{L}=$ labor employed and $\alpha=$ the level of technology. $\mathrm{K}$ and $\mathrm{L}$ have positive but diminishing marginal products. We extended the above cob-Douglas production function, to incorporate Governance (ICRG), inflation (INF) and trade openness (TRADE) and the function turns out to be as:

$$
Y=\alpha \text { CAPITAL } \beta 1 \text { LABOR } \beta 2 \text { ICRG } \beta 3 \text { INF } \beta 4 \text { TRADE } \beta 5
$$

By taking the log of variables on both sides and introducing error term, the final form of the model can be written as

$$
\ln Y=\alpha+\beta 1 \ln C A P I T A L+\beta 2 \ln l a b o r+\beta 3 \ln I C R G+\beta 4 \ln I N F+\beta 5 \ln T R A D E+\mu
$$


Where LN=natural log; GDP =GDP per capita (constant 2000 US\$), GFCF=Gross fixed capital formation (\% of GDP), Labor=life expectancy at birth (proxy for quality of labor), ICRG=Index used for governance quality taken from international country risk guide, INF= Inflation, GDP deflator (annual \%) Trade =Trade Openness (Exports+ Imports as \% of GDP), $\mu=$ error term

In time series econometrics we start analysis firstly by checking the unit root properties of the data. Normally ADF test is applied to check whether the data is stationary or non-stationary. Any linear combination of I(1) variables is typically spurious. But in the presence of some linear relationship between two I(1) series, if disturbances become zero and have tendency to disappear then such two series are said to be co-integrated because their residuals are stationary and have zero mean. ADF test is normally used to test the unit root property of different time series. And if the series is found to be integrated of order I(1), it is an indication that both the series have long run relationship and cointegration can be used. Engle and Granger (1987)claimed that we can get a stationary linear combination (called co-integrating equation and interpreted as long run equilibrium) of two or more non-stationary series. A variety of techniques like Engle-Granger, Engle-Granger 2 step method Johansen technique can be applied to determine this long run relationship. We have employed Johansen technique in this particular study.

\section{Results and Discussion}

Augmented Dickey Fuller test is operated first of all to examine the integration order and to deal with the issue of non-stationarity of variables if exists. Results of ADF test are given in Table 1.

Table 1: Results of ADF Test at First Difference

\begin{tabular}{|c|c|c|c|c|}
\hline \multirow[b]{2}{*}{ VARIABLES } & Constant & Constant\& Trend & Constant & $\&$ Trend \\
\hline & Level & \multicolumn{3}{|c|}{ First Difference } \\
\hline LNGDP & 0.113407 & -1.83396 & $-3.438272^{* *}$ & -3.40534 \\
\hline LNGFCFP & -2.733692 & -3.051413 & $-3.408125^{* *}$ & -3.350069 \\
\hline LNLABOR & -0.047051 & -1.865389 & $-3.408603^{* *}$ & -3.359564 \\
\hline LNICRG & -1.518598 & -1.868768 & $-6.764937^{*}$ & -6.370095 \\
\hline LNINF & -3.564261 & -3.798864 & $-7.306951^{*}$ & -7.124142 \\
\hline LNTRADE & 0.140630 & -1.422992 & $-3.931115^{*}$ & -3.861599 \\
\hline
\end{tabular}

All the series is non-stationary at level but becomes stationary at 1st difference which is an indication of the fact that all the variables to be used in the model have same integration order (i.e., I (1)). As Engle and Granger (1987) pointed out that a linear combination of two or more non-stationary series may be stationary and a long run relationship exists between these series. Johansen technique based on VARs not just gives method for testing co-integration but also for estimating co-integration systems. Results of the Johansen test are reported in the next part.

Table 2: Optimal Lag Lengths

\begin{tabular}{lllllll}
\hline Lag & Log L & LR & FPE & AIC & SC & HQ \\
\hline & & & & & & \\
0 & 251.9183 & NA & $2.08 \mathrm{e}-17$ & -21.38420 & -21.08798 & -21.30970 \\
1 & 405.6292 & $213.8587^{*}$ & $8.41 \mathrm{e}-22$ & -31.61993 & $-29.54642^{*}$ & -31.09845 \\
2 & 450.6982 & 39.19042 & $8.37 \mathrm{e}-22^{*}$ & $-32.40854^{*}$ & -28.55773 & $-31.44007^{*}$ \\
\hline
\end{tabular}

*indicates lag order selected by the criterion

LR: sequential modified LR test statistic (each test at 5\% level);FPE: Final prediction error;AIC: Akaike information criteria; SC: Schwarz information criteria; HQ: Hannan-Quinn information criteria. We can see that two lag have been selected by FPE, AIC and HQ criteria. 
Table 3: Rank Test for co-integration(Johansen)-Trace Test Statistics

\begin{tabular}{lllll}
\hline $\begin{array}{l}\text { Null } \\
\text { Hypothesis }\end{array}$ & $\begin{array}{l}\text { Alternative } \\
\text { Hypothesis }\end{array}$ & Test statistic & Critical Value (5\%) & Probability \\
\hline Ho: $r \leq 0$ & HA: $r>0$ & 172.9090 & 95.75366 & 0.0000 \\
Ho: $r \leq 1$ & HA: $r>1$ & 107.6376 & 69.81889 & 0.0000 \\
Ho: $r \leq 3$ & HA: $r>3$ & 71.87163 & 47.85613 & 0.0001 \\
Ho: $r \leq 4$ & HA: $r>4$ & 39.71490 & 29.79707 & 0.0026 \\
Ho: $r \leq 5$ & HA: $r>5$ & 22.11355 & 15.49471 & 0.0043 \\
\hline
\end{tabular}

*denotes rejection of the hypothesis at the 0.05 level

**Mackinnon-Haug-Michelis (19999) p-values

Table 4: Max-Eigenvalue test

\begin{tabular}{lllll}
$\begin{array}{l}\text { Null } \\
\text { Hypothesis }\end{array}$ & $\begin{array}{l}\text { Alternative } \\
\text { Hypothesis }\end{array}$ & $\begin{array}{l}\text { Test } \\
\text { statistic }\end{array}$ & Critical Value (5\%) & Probability \\
\hline Ho: $r=0$ & HA: $r=1$ & 65.27145 & 40.07757 & 0.0000 \\
Ho: $r=1$ & HA: $r=2$ & 35.76593 & 33.87687 & 0.0294 \\
Ho: $r=2$ & HA: $r=3$ & 32.15672 & 27.58434 & 0.0120 \\
Ho: $r=3$ & HA: $r=4$ & 17.60136 & 21.13162 & 0.1455 \\
Ho: $r=4$ & HA: $r=5$ & 13.80011 & 14.26460 & 0.0591 \\
\hline
\end{tabular}

$*$ denotes rejection of the hypothesis at the 0.05 level.

In Table 3 and 4 two tests for Johansen co-integration namely Max-eigenvalue value test and trace statistics is given. The test is related to the rank of the matrix (ignoring theory behind for the time being). Important fact to be considered is the value of the rank. If it is zero then there is no co-integration equation and if the rank is 1 there is one and if two there are two and so on. Here in our tests, Trace test indicates 5 cointegratingeqn(s) at the 0.05 level and Max-eigenvalue test indicates 3 co-integratingeqn(s) at the 0.05 level.

Table 5: Normalized Co-integrating Equation

\begin{tabular}{llllll}
\hline LNGDP & LNGFCF & LNLABOR & LNICRG & LNINF & LNTRADE \\
\hline 1 & 0.006216 & 6.53237 & 0.00308 & -0.001088 & 0.02671 \\
Std. Error & 0.00205 & 0.03484 & 0.00087 & -0.00026 & 0.00347 \\
t- Ratios & 3.0322 & 187.4961 & 3.53908 & 4.18462 & 7.697695 \\
\hline
\end{tabular}

The study has tried to incorporate governance quality in the neo classical framework of growth. As stated earlier in this paper that since 1990s political factors have been given great importance in the growth literature. However, we find mixed evidence on the role of institutions for growth in the empirical literature. That is why we have conducted an empirical test to check governance growth relationship. We have used a Cobb Douglas production function including the conventional sources of growth like labor, capital and trade. In addition, we used ICRG to check the impact of the quality of institutions and good governance on the GDP growth of Pakistan during the studied period. Results of the study show that all the variables are significantly affecting gross domestic product of Pakistan. Governance is affecting GDP positively. We have the expected results and the same is also proved by Kaufmann et al. (2002), Knack (2002) and Olson et al. (2000). Pakistan is facing many challenges in achieving good governance. It is deemed necessary that governance and quality of institutions must be improved so that Pakistan can achieve a sustained level of GDP growth. Other variables of the model are also significant and have expected signs. Labor force and trade openness are positively associated with GDP growth in our model. Inflation has negative impact on economy of Pakistan in this analysis. 


\section{Conclusion and Policy Recommendations}

Conventional sources of growth like labor, capital, aid, geographical effects, foreign trade, FDI and many other have been given tremendous importance in the neo-classical growth literature. Nevertheless, since 1990 governance has gained immense importance in international policy debates for explaining difference in growth patterns of different economies (Fayissa and Nsiah, 2010). Present study is an empirical test being conducted on Pakistan economy using data from 1984 to 2010 to determine the relation between growth and governance. ADF test is applied to check the order of integration of the series. On the basis of the ADF results Johansen Co-integration test is applied for econometric testing of the hypothesis. All the variables turned out to be significant with ICRG (proxy used for governance) having positive and significant impact on GDP of Pakistan. Gross fixed capital formation and inflation has negative impact on GDP in this study while trade openness and labor force having positive relation with GDP of Pakistan. Recognizing and supporting the positive role of governance for economic growth of Pakistan with our empirical model, we recommend improving economic, political and institutional governance. Proper management of financial system and increasing accountability and veracity in the public sector, free media, reform of the legal and judicial system, revision of economic policies and a stable political structure can help to improve governance in Pakistan.

\section{References}

Barro, R. J. (1991). Economic growth in a cross section of countries.The quarterly journal of economics, 106(2), 407-443.

Bauck, P., Strand, A. \& Gul, S. (2011). Review of and recommendations for Norwegian support to good governance in Pakistan. Norad Discussion Report (pp. 84). Oslo: Norwegian Agency for Development Cooperation.

Campos, N. F. \& Nugent, J. B. (1999). Development performance and the institutions of governance: Evidence from East Asia and Latin America. World development, 27(3), 439-452.

Chaudhry, I. S., Malik, S., Khan, K. N. \& Rasool, S. (2009). Factors Affecting Good Governance in Pakistan: An Empirical Analysis. European Journal of Scientific Research, 35(3), 337-346.

Chauvet, L. \& Collier, P. (2004). Development effectiveness in fragile states: spillovers and turnarounds. Centre for the Study of African Economies, Department of Economics, Oxford University.

Cobb, C. W. \& Douglas, P. H. (1928).A theory of production. The American economic review, 18(1), 139-165.

Engle, R. F. \& Granger, C. W. (1987). Co-integration and error correction: representation, estimation, and testing. Econometrica: journal of the Econometric Society, 55, 251-276.

Fayissa, B. \& Nsiah, C. (2010). The Impact of Governance on Economic Growth: Further Evidence for Africa. Department of Economics and Finance. Working Paper Series, (December).

Haq, R. \& Zia, U. (2009). Does Governance Contribute to Pro-Poor Growth? Evidence from Pakistan: Pakistan Institute of Development Economics, Working Paper 52.

Husain, I. (2005). Economy of Pakistan: an overview. Paper presented at the Key Note Address at the Expo 2005 Conference held at Karachi on February 3, 2005.

Hussain, A. (2004). Pakistan national human development report 2003: poverty, growth and governance: Oxford University Press, USA

Jalilian, H., Kirkpatrick, C. \& Parker, D. (2007). The impact of regulation on economic growth in developing countries: A cross-country analysis. World development, 35(1), 87-103.

Kaufmann, D. \& Kraay, A. (2002). Growth without governance. World Bank Policy Research Working Paper(2928).

Kaufmann, D., Kraay, A. \& Mastruzzi, M. (2004). Governance matters III: Governance indicators for 1996, 1998, 2000, and 2002. The World Bank Economic Review, 18(2), 253-287.

Kaufmann, D., Kraay, A. \&Zoido, P. (2002). Governance matters II: updated indicators for 2000-01. World Bank Policy Research Working Paper(2772).

Keefer, P. \& Knack, S. (1997). Why Don't Poor Countries Catch Up? A Cross-National Test of an Institutional Explanation. Economic Inquiry, 35(3), 590-602.

Khan, M. H. (2006).Determinants of corruption in developing countries: the limits of conventional economic analysis. International Handbook on the Economics of Corruption: 216-244.

Knack, S. (2002). Social capital and the quality of government: Evidence from the States. American Journal of Political Science, 46(4), 772-785. 
Kormendi, R. C. \& Meguire, P. G. (1985). Macroeconomic determinants of growth: cross-country evidence. Journal of monetary economics, 16(2), 141-163.

Kuznets, S. (1966). Modern Economic Growth: Rate. Structure and Spread, New Haven: Yale University Press.

Maurseth, P. B. \& Verspagen, B. (2009). Europe: one or several systems of innovation? An analysis based on patent citations. Cornell family papers.

Mawdsley, E. \& Rigg, J. (2003). The World Development Report II: continuity and change in development orthodoxies. Progress in Development Studies, 3(4), 271-286.

Olson JR, M., Sarna, N. \& Swamy, A. V. (2000). Governance and growth: A simple hypothesis explaining cross-country differences in productivity growth. Public Choice, 102(3-4), 341-364.

Owens, E. (1987). The future of freedom in the developing world: Economic development as political reform: Pergamon Press New York.

Pasha, H. A. (2000). Elements of Good Economic Governance: Social Policy and Development Centre. (Research Report No. 30).

Resnick, D. \& Birner, R. (2006). Does good governance contribute to pro-poor growth?: A review of the evidence from cross-country studies: DSCD Discussion Paper 30. International Food Policy Research Institute (IFPRI), Washington.

Reynolds, L. G. (1983). The spread of economic growth to the third world: 1850-1980. Journal of Economic Literature, 21(3), 941-980.

Schwab (2010).The global competitiveness report 2010-2011. Geneva, Switzerland.

Sen, A. (1999). Development as freedom. Oxford University Press Paperback.

Shafique, S. \& Haq, R. (2006). Governance and Income Inequality. The Pakistan Development Review, 45(4), 751-760.

Solow, R. M. (1957). Technical change and the aggregate production function. The review of Economics and Statistics, 39(3), 312-320.

\section{Appendices}

Table 1: Pakistan's Rank and Score on the Global Competitiveness Index (2011)

\begin{tabular}{llll} 
GCR Report & Rank & Out of & Hard Score \\
\hline $2007-08$ & 92 & 131 & 3.77 \\
$2008-09$ & 101 & 134 & 3.65 \\
$2009-10$ & 101 & 133 & 3.58 \\
$2010-11$ & 123 & 139 & 3.5 \\
\hline
\end{tabular}

Source:Schwab (2010). The global competitiveness report 2010-2011. Geneva, Switzerland.

Table 2: Quality of Institutions

\begin{tabular}{lll}
\hline GCR Report & Rank & Score \\
\hline $2006-2007$ & 79 & \\
$2007-2008$ & 81 & 3.5 \\
$2008-2009$ & 95 & 3.3 \\
$2009-2010$ & 104 & 3.3 \\
$2010-2011$ & 112 & \\
\hline
\end{tabular}

Source:Schwab (2010). The global competitiveness report 2010-2011. Geneva, Switzerland.

Table 3: MACROECONOMIC STABILITY

\begin{tabular}{lll}
\hline GCR Report & Rank & Score \\
\hline $2006-2007$ & 86 & 4.2 \\
$2007-2008$ & 101 & - \\
$2008-2009$ & 116 & 3.8 \\
$2009-2010$ & 114 & 3.2 \\
$2010-2011$ & 133 & - \\
\hline Source:Schwab (2010). The global competitiveness report 2010-2011. Geneva, Switzerland.
\end{tabular}

Table 1.4: Largest Reversals in Country Rank for Pakistan 2010 Indicators 


\begin{tabular}{lllll}
\hline variables & $\mathbf{2 0 0 8}-$ & $\mathbf{2 0 0 9 -}$ & $\mathbf{2 0 1 0}-$ & $\begin{array}{l}\text { Difference(one } \\
\text { year) }\end{array}$ \\
\hline Inflation (change in CPI) & $\mathbf{2 0 0 9}$ & $\mathbf{2 0 1 0}$ & $\mathbf{2 0 1 1}$ & -34 \\
Interest rate spread & 95 & 103 & 137 & -30 \\
Trade Tariffs/Tariff barriers & 87 & 64 & 94 & -28 \\
Rigidity of employment & 120 & 105 & 133 & -23 \\
Agricultural policy costs & 84 & 87 & 110 & -18 \\
Total tax rate & 90 & 88 & 106 & -15 \\
Internet users & 58 & 22 & 37 & -15 \\
Burden of government regulation & 96 & 85 & 100 & -13 \\
Strength of auditing and reporting standards & 78 & 59 & 72 & -13 \\
Quality of overall infrastructure & 67 & 84 & 97 & -13 \\
Hiring and firing practices & 83 & 87 & 100 & -13 \\
Organized crime & 31 & 38 & 51 & -11 \\
Tuberculosis incidence (per 100K people) & 114 & 116 & 127 & -11 \\
Flexibility of wage determination & 102 & 102 & 113 & -11 \\
Transparency of government in policymaking & 95 & 93 & 104 & -10 \\
\hline
\end{tabular}

Source:Schwab (2010).The global competitiveness report 2010-2011.Geneva, Switzerland.

Figure 1: Voice \& Accountability (Percentile Rank)

Aggregate Indicator: Voice \& Accountabillity

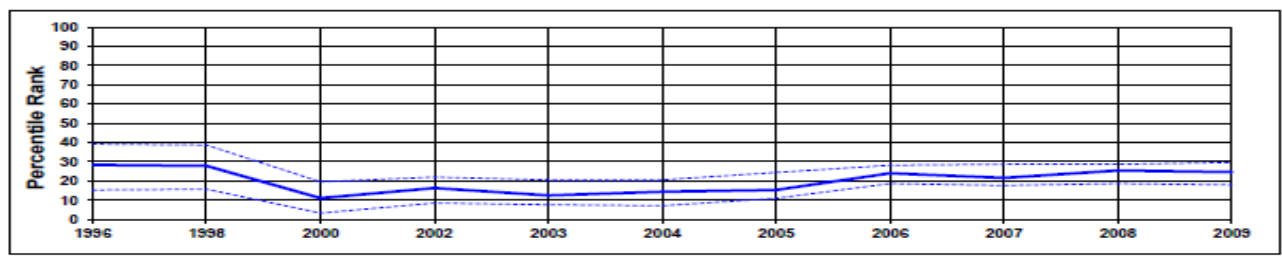

Source: world governance indicators (www.wdi.org.com)

Figure 2: Voice \& Accountability (Percent Score)

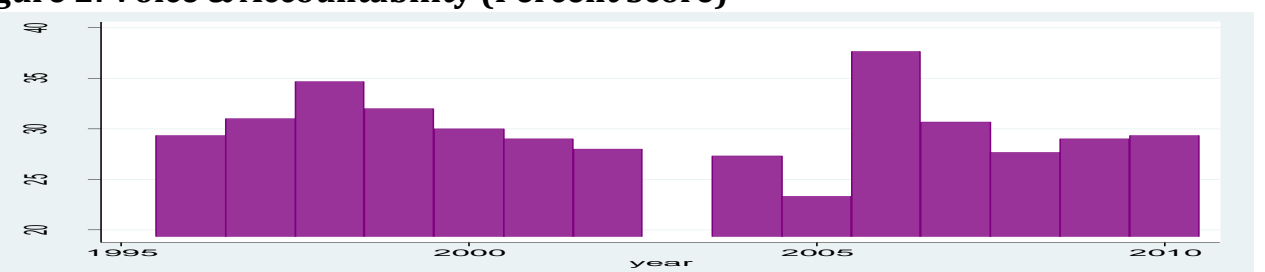

Source: world governance indicators (www.wdi.org.com)

Figure 3: Government Effectiveness (Percentile Rank)

Aggregate Indicator: Government Effectiveness

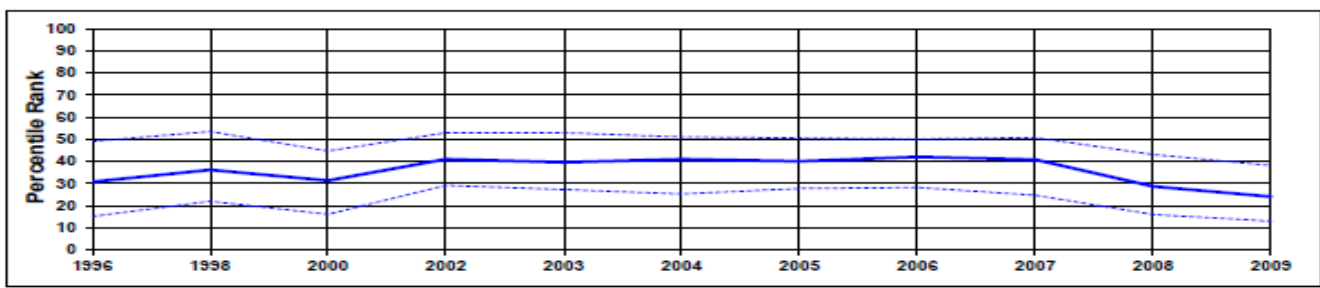

Source: world governance indicators (www.wdi.org.com)

Figure 4 Government Effectiveness (Percent Score) 


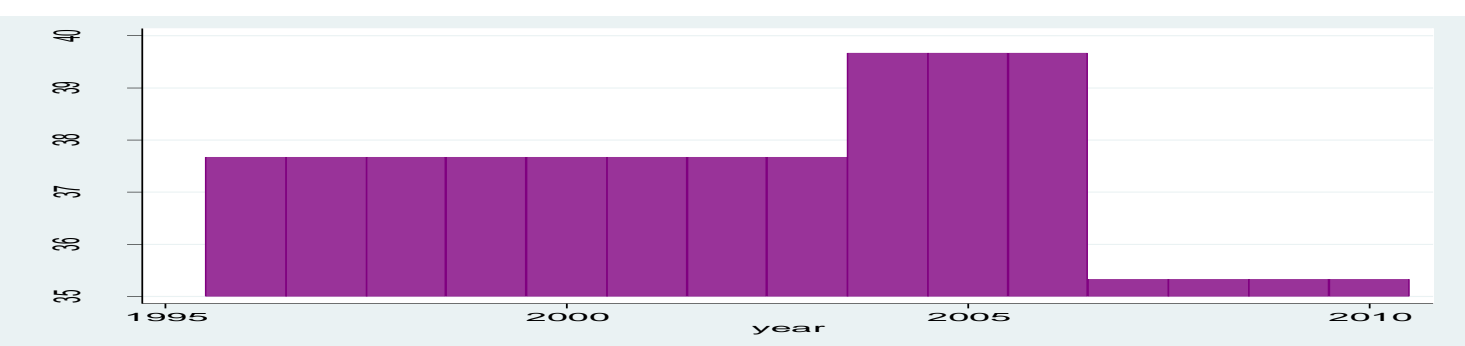

Source: world governance indicators (www.wdi.org.com)

\section{Figure 5: Rule of Law (Percentile Rank)}

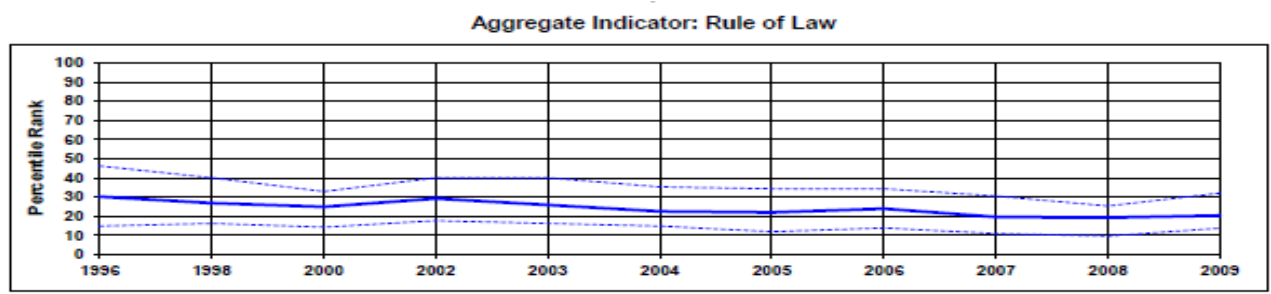

Source: world governance indicators (www.wdi.org.com)

Figure 6: Rule of Law (Percent Score)

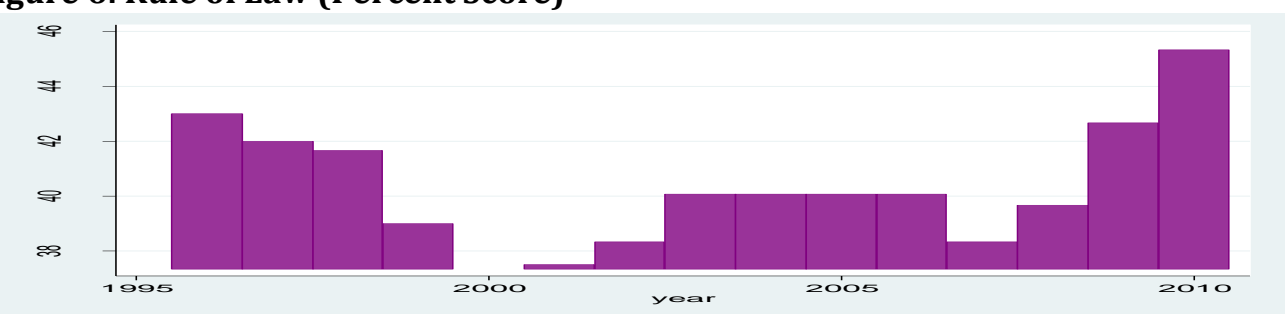

Source: world governance indicators (www.wdi.org.com)

Figure 7: Political Stability \& Absence of Violence (Percentile Rank)

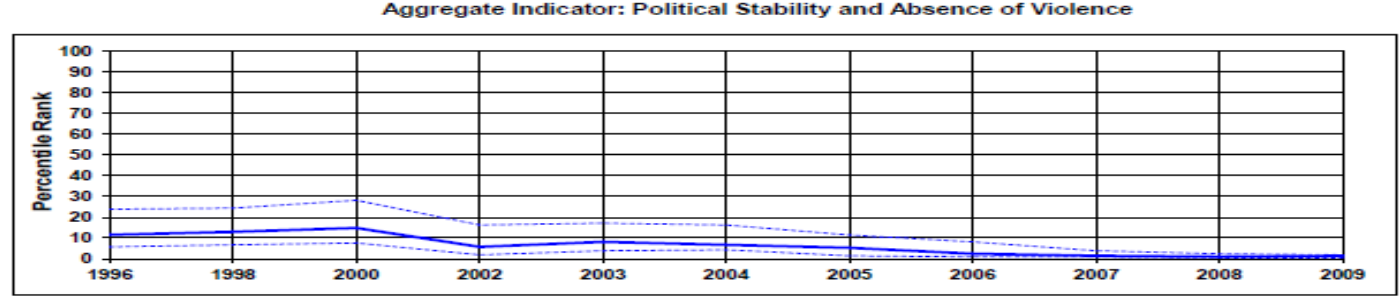

Source: world governance indicators (www.wdi.org.com)

Figure 8: Political Stability \& Absence of Violence (Percent Score) 


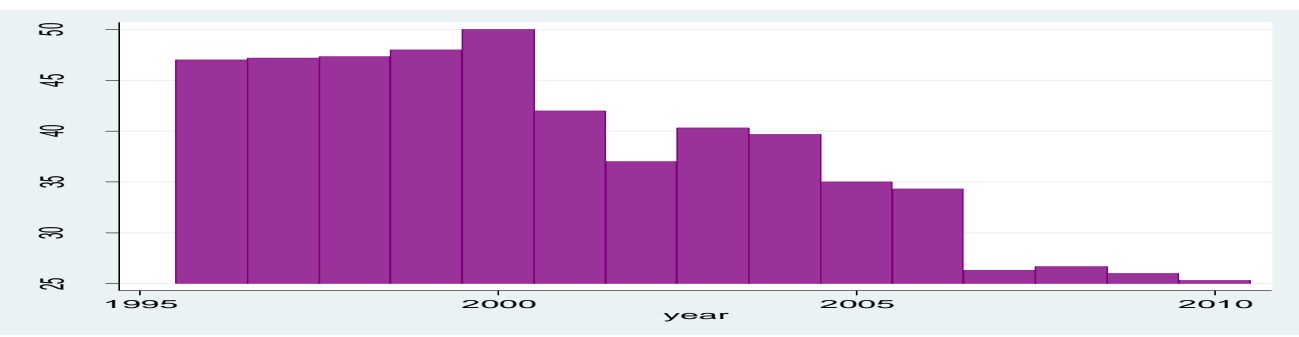

Source: world governance indicators (www.wdi.org.com)

Figure 9: Control of Corruption (Percentile Rank)

Aggregate Indicator: Control of Corruption

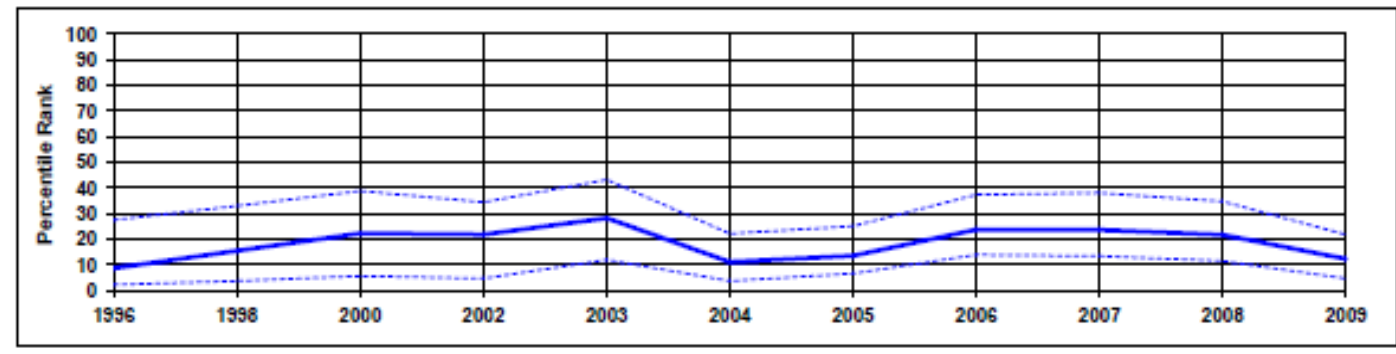

Source: world governance indicators (www.wdi.org.com)

Figure 10: Control of Corruption (Percent Score)

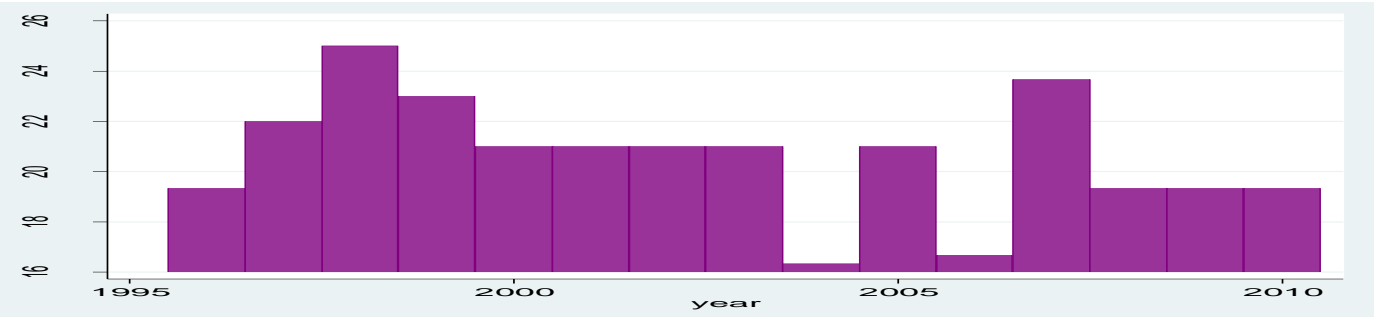

Source: world governance indicators (www.wdi.org.com)

Figure 11 Regulatory Quality (Percentile Rank)

Aggregate Indicator: Regulatory Quality

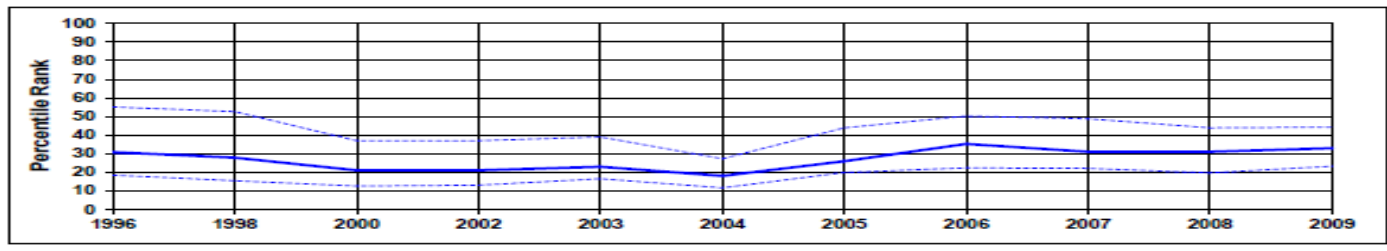

Source: world governance indicators (www.wdi.org.com)

Figure 12: Regulatory Quality (Percent Score)

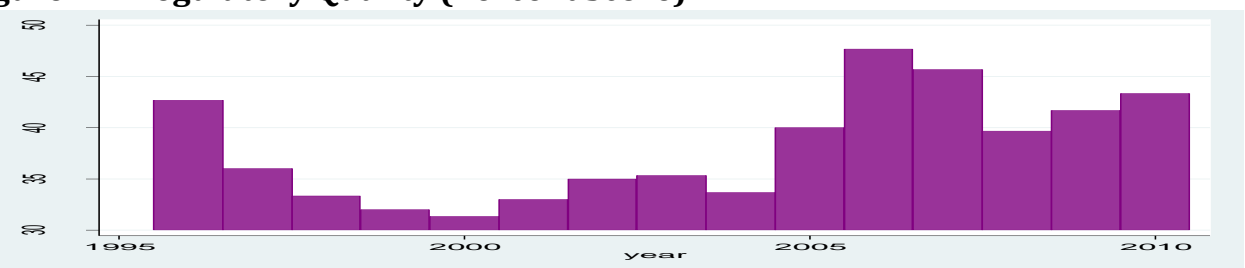

Source: world governance indicators (www.wdi.org.com) 